\title{
Occurrence of ochratoxin $A$ in grapes, juices and wines and risk assessment related to this mycotoxin exposure
}

\author{
Ocorrência de ocratoxina A em uvas, sucos e vinhos e avaliação de risco \\ relacionada à exposição a essa micotoxina
}

Bruna Dachery ${ }^{\mathrm{I}}$ Vitor Manfroi ${ }^{\mathrm{I}}$ Kally Janaina Berleze ${ }^{\mathrm{II}}$ Juliane Elisa Welke ${ }^{\mathrm{I}^{*}}$

- REVIEW -

ABSTRACT

Ochratoxin A (OTA) is a mycotoxin with nephrotoxic, genotoxic, teratogenic and carcinogenic properties. The presence of this toxin in wines and juices occurs due to the development of toxigenic fungi in grapes. Studies have shown the presence of this toxic secondary metabolite in these beverages may results in economic losses to the winery as well as health problems for consumers. In Europe, several studies have been done in order to map the areas where the development of ochratoxigenic fungi is more favorable. However, in Brazil these studies are still incipient. The Joint Expert Committee on Food Additives of the World Health Organization (JECFA) established the safe tolerable intake of $112 \mathrm{ng}$ OTA per $\mathrm{kg}$ of body weight per week. To verify whether the population is exposed to OTA levels that pose a risk to health is necessary to compare the parameter of safe ingestion defined by JECFA with the levels of exposure to this toxin. Periodic monitoring of the OTA levels in food and beverage has been justified by some reasons including: (i) the toxic effects of this toxin, (ii) the recent publication of the Brazilian legislation establishing maximum limit for OTA, (iii) the introduction of grape juice in school meals and (iv) the recommendation of regular wine intake because of their functional properties.

Key words: mycotoxins, risk assessment, toxic compounds.

RESUMO

A ocratoxina $A$ (OTA) é uma micotoxina que possui propriedades nefrotóxicas, genotóxicas, teratogênicas e carcinogênicas. A presença dessa toxina em vinhos e sucos ocorre devido à contaminação das uvas por fungos toxigênicos. Estudos têm mostrado a presença desse metabólito secundário tóxico nestas bebidas, o que pode significar perdas econômicas ao setor vitícola, bem como problemas à saúde dos consumidores. Na Europa, vários estudos têm sido realizados com o objetivo de mapear as áreas em que o desenvolvimento de fungos ocratoxigênicos é mais favorável. Entretanto, no Brasil estes estudos ainda são incipientes. O Comitê de Especialistas em Aditivos Alimentares da Organização Mundial da Saúde (JECFA) estabeleceu a ingestão tolerável segura de $112 \mathrm{ng}$ de OTA por quilo de peso corpóreo por semana. Para verificar se população está exposta a OTA em níveis que representam risco para à saúde, é necessário comparar o parâmetro de ingestão segura, definido pelo JECFA, com os níveis de exposição a esta toxina. O monitoramento periódico dos niveis de OTA em alimentos e bebidas é justificado por alguns motivos que incluem: (i) os efeitos tóxicos dessa toxina, (ii) a publicação recente da legislação brasileira que estabelece limite máximo para OTA, (iii) a introdução do suco de uva na merenda escolar; e (iv) a recomendação da ingestão regular de vinho/suco de uva devido as suas propriedades funcionais.

Palavras-chave: micotoxinas, avaliação de risco, compostos tóxicos.

\section{INTRODUCTION}

The grapes are subject to fungal contamination during cultivation, harvest, transport and/or storage. Mycotoxins are products of secondary metabolism of some filamentous fungi. Production of these toxic compounds is influenced by several factors, including humidity, temperature, substrate composition, water activity, $\mathrm{pH}$ and fungal strain (MARROQUÍN-CARDONA et al., 2014). Ochratoxin A (OTA) is a mycotoxin that has nephrotoxic, genotoxic, teratogenic and carcinogenic properties (ROCHA et al., 2014). In this way, the International Agency for Research on

Instituto de Ciência e Tecnologia de Alimentos, Universidade Federal do Rio Grande do Sul (URFGS), Avenida Bento Gonçalves, n. 9500 , 91501-970, Porto Alegre, RS, Brasil. E-mail: juliane.welke@ufrgs.br. "Corresponding author.

IUniversidade de Caxias do Sul (UCS), Caxias do Sul, RS, Brasil. 
Cancer (IARC) has classified OTA in group 2B, ie, as a possible carcinogen to humans (IARC, 1993). Because of the toxicity of OTA, the maximum limit of $2 \mathrm{ng} \mathrm{mL} \mathrm{mL}^{-1}$ was established for grape juice and wine by Brazilian legislation (ANVISA, 2011). This same limit is adopted in countries of the European Union (EUROPEAN COMISSION, 2006).

The use of grapes that contains OTA for the preparation of juices and wines may be a concern, since grape juices may be widely consumed by children and even are used in school meals in some Brazilian states, such as Rio Grande do Sul and Santa Catarina (RIO GRANDE DO SUL, 2009; SANTA CATARINA, 2009). The incentive to grape derivatives consumption occurs due to the presence of phenolic compounds and stilbene which reduce the risk of cardiovascular diseases and have antioxidant and anti-inflammatory properties (XIANG et al., 2014).

The objective of this review was to determine, based on research published in the literature, if the world population is exposed to OTA through the consumption of juices and wines at levels that pose risk to health. The factors related to the development ochratoxigenic fungi in grapes and occurrence of this mycotoxin in the juices and wines were reviewed. The databases used in this research were "Web of Science" and "Scopus" from September 2104 to March 2015. The keywords used for search data were "Ochratoxin wine" and "Ochratoxin juice".

Occurrence and factors related to the incidence of OTA-producing fungi in grapes

The main OTA-producing fungi in grapes belong to the genus Aspergillus. Two sections of Aspergillus are known as OTA-producing: Circumdati (group that belongs the A. ochraceus) and Nigri (group in which are classified $\boldsymbol{A}$. carbonarius and $\boldsymbol{A}$. niger). The contamination of grapes with Aspergillus may be minimized by cultivating grapes more resistant to pests and utilization of practices of harvesting and transportation that preserve the integrity of the grapes. The presence of OTA-producing fungi has been occurred in different countries with wine tradition in wine production, incuding Argentina (PONSONE et al., 2007; CHIOTTA et al., 2009), France (CLOUVEL et al., 2008), Italy (LUCCHETTA et al., 2010) and Tunisia (LASRAM et al., 2012).

The incidence of OTA-producing fungi in grapes of varieties Bonarda and Tempranillo produced in Argentina was verified by PONSONE et al. (2007). OTA was not found in grapes, however, several species of Aspergillus were isolated from grapes, including, A. japonicus (40\%), A. niger
(34\%), A. awamori (15\%), A. foetidus (4\%), A. aculeatus (4\%) and $A$. carbonarius (3\%), of these, $24 \%$ were identified as OTA producers.

CHIOTTA et al. (2009) found 284 fungal isolates identified as Aspergillus section Nigri in grapes cultivated in Argentina. A. niger (81\%), A. carbonarius (11\%) and $A$. uniseriate (8\%) were the species isolated from grapes, that included $32 \%$ of OTA-producers (69\% of $\boldsymbol{A}$. niger and $31 \%$ of $\boldsymbol{A}$. carbonarius).

CLOUVEL et al. (2008) observed that the presence of the Botrytis cinerea and Lobesia botrana incresead the contamination by $A$. carbonarius in grapes grown in southern France, achieving 5.8ng $\mathrm{mL}^{-1}$ of OTA. These vectors damage the surface of the grapes and thus facilitate the colonization of $\boldsymbol{A}$. carbonarius. LUCCHETTA et al. (2010) evaluated the presence of OTA producing fungi in grapes grown in the northern, central and southern Italy. $\boldsymbol{A}$. carbonarius was found mainly in grapes produced in the south region, while $\boldsymbol{A}$. niger was predominant in Northern and Central region. The grapes from the south showed more frequent incidence (45\%) and highest concentration of OTA (reaching of 9.2ng $\mathrm{mL}^{-1}$ of OTA). The differences in fungal incidence and OTA levels of grapes grown in different regions may occur due to climatic factors of each region. In the southern region of Italy, for example, the climate is more humid and warm and in these conditions, the concentration of OTA in grapes can reach high levels.

LASRAM et al. (2012) evaluated the occurrence of toxigenic fungi and OTA in grapes grown in different regions of Tunisia. A. niger was the predominant specie isolated from grapes $(75 \%)$, followed by $\boldsymbol{A}$. carbonarius (22\%). However, only $3 \%$ of A. niger showed potential to produce OTA, while $97 \%$ of $\boldsymbol{A}$. carbonarius were OTA-producers. OTA was found in $38 \%$ of grapes in levels ranging from 0.05 a $5.85 \mathrm{ng} \mathrm{mL}^{-1}$.

The ochratoxigenic effect of $A$. carbonarius was evaluated in damage and undamage grapes by BELLÍ et al. (2007). These grapes were storage at 20 and $30^{\circ} \mathrm{C}$ and humidaty of 80,90 and $100 \%$. The higher levels of OTA were found in damage grapes, storage at $30^{\circ} \mathrm{C}$ and $100 \%$ of humidity.

\section{Occurrence of OTA in grape juice and wine}

After cereals, juices and wines are the largest sources of exposure to OTA. Since OTA was first detected in these beverages sold in Switzerland (ZIMMERLI \& DICK, 1996), several studies about the occurrence of OTA are found in the literature (Table 1 and 2). The concentration of OTA in juice 
Table 1 - Occurrence of ochratoxin A in grape juices in different countries.

\begin{tabular}{|c|c|c|c|c|c|}
\hline Country & $\begin{array}{l}\text { Incidence } \\
(\%)\end{array}$ & Range (ng $\mathrm{mL}^{-1}$ ) & $\begin{array}{l}\text { Estimated } \\
\text { exposure "A" (ng } \\
\left.\mathrm{kg}^{-1} \text { bw day }{ }^{-1}\right)^{\mathrm{a}}\end{array}$ & $\begin{array}{l}\text { Estimated } \\
\text { exposure "C" (ng } \\
\left.\mathrm{kg}^{-1} \text { bw day }{ }^{-1}\right)^{\mathrm{b}}\end{array}$ & Reference \\
\hline 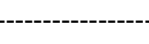 & & & --Red juices---- & --------------- & ----------- \\
\hline \multirow[t]{2}{*}{ Germany } & 78 & $0.02-6.72$ & $0.05-16.24^{c}$ & $0.2-67.20^{\mathrm{c}}$ & WOESE, 2000 \\
\hline & 11,1 & $0.008-0.104$ & $0.02-0.25$ & $0.08-1.04$ & NG et al., 2004 \\
\hline \multirow[t]{3}{*}{ Brazil } & 29,2 & $0.021-0.1$ & $0.05-0.24$ & $0.21-1.00$ & ROSA et al,, 2004 \\
\hline & $\mathrm{ND}^{\mathrm{d}}$ & $<0.03$ & $<0.07$ & $<0.30$ & SHUNDO et al., 2006 \\
\hline & $\mathrm{ND}^{\mathrm{d}}$ & $<0.01$ & $<0.02$ & $<0.10$ & TERRA et al., 2012 \\
\hline China & 30 & $0.26-0.54$ & $0.63-1.31$ & $2.60-5.40$ & CAO et al., 2013 \\
\hline Spain & $\mathrm{ND}^{\mathrm{d}}$ & $<0.05$ & $<0.12$ & $<0.50$ & BELLÍ et al., 2004 \\
\hline Malaysia & 91 & $<0.02-1.05$ & $<0.05-2.54$ & $0.20-10.5$ & LEE et al., 2012 \\
\hline Switzerland & 100 & $<0.003-0.311$ & $<0.007-0.75$ & $0.03-3.11$ & ZIMMERLI \& DICK, 1996 \\
\hline Canada & 16 & $0.008-0.071$ & $0.02-0.17$ & $0.08-0.71$ & NG et al., 2004 \\
\hline
\end{tabular}

${ }^{a}$ Estimated exposure "A": Estimated exposure to OTA ( $\mathrm{ng} \mathrm{kg}^{-1} \mathrm{bw}$ day ${ }^{-1}$ ) for adults (considering the body weight of $60 \mathrm{~kg}$ ) through the daily consumption of $145 \mathrm{~mL}$ of juice, as established by the Consumer Expenditure Survey (IBGE, 2011).

bEstimated exposure "C": Estimated exposure to OTA (ng kg ${ }^{-1}$ bw day ${ }^{-1}$ ) for children (considering the body weight of $20 \mathrm{~kg}$ ) through the daily consumption of $200 \mathrm{~mL}$ of juice in scholar meals.

${ }^{c}$ Estimated exposure to OTA may be greater than provisional tolerable intake for this mycotoxin $\left(16 \mathrm{ng} \mathrm{kg}^{-1} \mathrm{bw} \mathrm{day}^{-1}\right)(\mathrm{JECFA}, 2007)$, if these samples were consumed.

${ }^{\mathrm{d}} \mathrm{ND}$ : OTA were not detected.

and wine is often reported below of legislation limit (2ng mL ${ }^{-1}$ ) (WOESE, 2000; NG et al., 2004; ROSA et al., 2004; SHUNDO et al., 2006; QUINTELA et al., 2012; CAO et al., 2013; LASRAM et al., 2013).

The maceration of the grapes is the main processing step that contributes to the OTA contamination of juice and wine, since the contact of grape skin during this stage facilitates the migration of toxin to must (WELKE et al., 2009). For this reason, in general, OTA levels are higher in red wines (in which maceration is necessarily done in contact with grape skin), followed by roses and whites wines (OTTENEDER \& MAJERUS, 2000; CABANES et al., 2002). BRERA et al. (2008) confirmed this fact analyzing 1166 samples of wines from different regions of Italy. The maximum values were $7.50 \mathrm{ng} \mathrm{mL}^{-1}$ for red, $4.07 \mathrm{ng} \mathrm{mL}^{-1}$ for rosés, $1.95 \mathrm{ng} \mathrm{mL}^{-1}$ for whites. In addition, the wines produced in the southern region of Italy had higher values of OTA compared to the north. The authors suggest that the difference of latitude (from $46.8^{\circ} \mathrm{N}$ to $36.8^{\circ} \mathrm{S}$ ) and climate between the north and south regions may influence the OTA levels.

Special wines such as fortified or dessert wines have high sugar concentration, thus, the probability of fungal contamination, including ochratoxigenic fungi, is increased in these wines. The late harvest (when the grapes have excessive degree of ripeness) may be used to concentrate more sugar in grapes used in winemaking. An alternative to the production of these more sweet wines consists in interrupting the fermentation by fortification with grape wine distillate. This procedure also provides that the characteristic alcohol level of this beverage is achieved, since the fermentation was terminated. In this way, enological practices influence the concentration of OTA (PIETRI et al., 2001; BELLI et al., 2004; RATOLA et al., 2005; CHIODINI et al., 2006). VALERO et al. (2008) found high levels of OTA in wines produced using grapes with excessive degree of ripeness $\left(15.62 \mathrm{ng} \mathrm{ml}^{-1}\right)$ and fortified wines (27.79ng ml-1) elaborated with grape wine distillate.

Risk assessment related to OTA exposure through consumption of grape juice and wine

In 2001, The Joint FAO/WHO Expert Committee on Food Additives (JECFA) established a provisional tolerable weekly intake (PTWI) for OTA of $112 \mathrm{ng} \mathrm{kg}^{-1}$ body weight (bw), which corresponds to approximately $16 \mathrm{ng} \mathrm{kg}^{-1}$ pc per day (JECFA, 2007). The concept of provisional tolerable intake is based on the amount of a compound that can be consumed during the lifetime of an individual without causing damage to their health. In this way, the comparison of OTA exposure with PTWI may be used to evaluate the potential risks to human health. If the estimated 
Table 2 - Occurrence of ochratoxin A in wines produced in different places and evaluation of the estimated exposure to this mycotoxin.

\begin{tabular}{|c|c|c|c|c|}
\hline Place & $\begin{array}{l}\text { Incidence (\%) } \\
{\text { [type }]^{\mathrm{a}}}\end{array}$ & Range (ng mL ${ }^{-1}$ ) & $\begin{array}{l}\text { Estimated exposure } \\
\left(\mathrm{ng} \mathrm{kg}^{-1} \text { bw day }\right)^{-1}\end{array}$ & Reference \\
\hline Africa & $100[\mathrm{R}]$ & $0.0844-0.455$ & $0.21-1.14$ & REMIRO et al., 2013 \\
\hline South Africa & $100[\mathrm{R}]$ & $<0.03$ & $<0.07$ & SHUNDO et al., 2006 \\
\hline \multirow[t]{2}{*}{ Argentina } & $17[\mathrm{R}]$ & $<0.03$ & $<0.07$ & SHUNDO et al., 2006 \\
\hline & $\mathrm{ND}[\mathrm{R}]$ & $<0.20$ & $<0.50$ & HOELTZ et al., 2012 \\
\hline Australia & $50[\mathrm{R}]$ & $<0.033-0.072$ & $<0.08-0.18$ & QUINTELA et al., 2012 \\
\hline \multirow[t]{6}{*}{ Brazil } & $3[\mathrm{R}]$ & $<0.016-4.50[3 \%]^{\mathrm{b}}$ & $<0.04-11.25$ & WELKE et al., 2010 \\
\hline & $6[\mathrm{R}]$ & $<0.80-0.84$ & $<2.00-2.10$ & TEIXEIRA at al., 2011 \\
\hline & $31[\mathrm{R}]$ & $<0.10-1.33$ & $0.25-3.32$ & SHUNDO et al., 2006 \\
\hline & $\mathrm{ND}[\mathrm{R}]$ & $<0.20$ & $<0.50$ & HOELTZ et al., 2012 \\
\hline & $75[\mathrm{R}]$ & $<0.03-0.62$ & $0.07-1.55$ & TERRA et al., 2012 \\
\hline & $14.3[\mathrm{~W}]$ & $<0.03$ & $<0.07$ & TERRA et al., 2012 \\
\hline \multirow[t]{2}{*}{ Canada } & $14[\mathrm{~W}]$ & $<0.004-0.156$ & $<0.01-0.39$ & NG et al., 2004 \\
\hline & $23[\mathrm{R}]$ & $<0.008-0.393$ & $<0.02-0.98$ & NG et al., 2004 \\
\hline Chile & $\mathrm{ND}[\mathrm{R}]$ & $<0.20$ & $<0.50$ & HOELTZ et al., 2012 \\
\hline \multirow[t]{7}{*}{ China } & $10[\mathrm{~W}]$ & $<0.09-0.53$ & $<0.22-1.32$ & WU et al., 2011 \\
\hline & $29[\mathrm{R}]$ & $<0.02-1.18$ & $<0.05-2.95$ & WU et al., 2011 \\
\hline & $57[\mathrm{R}]$ & $<0.03-5.65[39.5 \%]^{\mathrm{b}}$ & $<0.07-14.12$ & ZHANG et al., 2013 \\
\hline & $2,9[\mathrm{~W}]$ & $<0.03-0.07$ & $<0.07-0.17$ & ZHANG et al., 2013 \\
\hline & $25[\mathrm{RO}]$ & $<0.03-0.22$ & $<0.07-0.55$ & ZHANG et al., 2013 \\
\hline & $28[\mathrm{R}]$ & $<0.0028-0,0437$ & $<0.007-0.11$ & MAO et al., 2013 \\
\hline & $45[\mathrm{R} ; \mathrm{W}]$ & $<0.01-0.98$ & $<0.025-2.45$ & ZHONG et al., 2014 \\
\hline Croatia & $100[\mathrm{R}]$ & $0.00003-0.0613$ & $0.00007-0.15$ & REMIRO et al., 2013 \\
\hline \multirow[t]{7}{*}{ Spain } & 80 & $<0.11-1.3$ & $<0.27-3.25$ & BELLÍ et al., 2004 \\
\hline & $100[\mathrm{RO}]$ & $0.007-0.09$ & $0.017-0.22$ & CHIODINNI et al., 2006 \\
\hline & $100[\mathrm{R}]$ & $0.064-0.138$ & $0.16-0.35$ & QUINTELA et al., 2012 \\
\hline & $100[\mathrm{R}]$ & $0.07-0.2$ & $0.175-0.50$ & SHUNDO et al., 2006 \\
\hline & $100[\mathrm{R}]$ & $0.001-0.104$ & $0.002-0.26$ & REMIRO et al., 2013 \\
\hline & $100[\mathrm{R}]$ & $0.00049-0.0949$ & $0.001-0.23$ & REMIRO et al., 2012 \\
\hline & $19[\mathrm{R}]$ & $<0.06-4.24[4,3 \%]^{\mathrm{b}}$ & $<0.15-10.60$ & BELLÍ et al., 2004 \\
\hline Europe $^{\mathrm{e}}$ & $91[\mathrm{~S}]$ & $<0.024-27.79[55]^{\mathrm{b}}$ & $<0.06-69.50^{\mathrm{d}}$ & VALERO et al. (2008) \\
\hline \multirow[t]{3}{*}{ France } & $93[\mathrm{R}]$ & $<0.010-0.237$ & $<0.025-0.60$ & QUINTELA et al., 2012 \\
\hline & $60[\mathrm{R}]$ & $<0.20-0.29$ & $<0.5-0.72$ & SHUNDO et al., 2006 \\
\hline & $92[\mathrm{R}]$ & $<0.0003-0.0883$ & $<0.0007-0.22$ & REMIRO et al., 2013 \\
\hline \multirow[t]{4}{*}{ Greece } & 89 [W] & $<0.01-0.56$ & $<0.025-1.4$ & SARIGIANNIS et al., 2014 \\
\hline & $100[\mathrm{RO}]$ & $0.19-2.52[50 \%]^{\mathrm{b}}$ & $0.47-6.3$ & SARIGIANNIS et al., 2014 \\
\hline & $73[\mathrm{R}]$ & $<0.01-0.71$ & $0.025-1.78$ & SARIGIANNIS et al., 2014 \\
\hline & $100[\mathrm{R}]$ & $0.004-0.212$ & $0.01-0.53$ & REMIRO et al., 2013 \\
\hline \multirow[t]{9}{*}{ Italy } & $94[\mathrm{R}]$ & $<0.075-0.941$ & $<0.18-2.35$ & GIOVANNOLI et al., 2014 \\
\hline & $6.7[\mathrm{R}]$ & $<0.12-2.69[6.7 \%]^{b}$ & $<0.3-6.72$ & PRELLE et al., 2013 \\
\hline & $100[\mathrm{R}]$ & $0.050-0.353$ & $0.12-0.88$ & QUINTELA et al., 2012 \\
\hline & $95[\mathrm{R}]$ & $<0.005-7.5[2,8 \%]^{\mathrm{b}}$ & $<0.0125-18.75$ & BRERA et al., 2008 \\
\hline & $100[\mathrm{R}]$ & $0.03-0.33$ & $0.075-0.82$ & SHUNDO et al., 2006 \\
\hline & $100[\mathrm{R}]$ & $0.0051-0.286$ & $0.01-0.71$ & REMIRO et al., 2013 \\
\hline & $97.4[\mathrm{R}]$ & $<0.01-7.63$ & $<0.025-19.01^{\mathrm{d}}$ & VISCONTI et al., 1999 \\
\hline & $87.5[\mathrm{RO}]$ & $<0.01-1.15$ & $<0.025-2.88$ & VISCONTI et al., 1999 \\
\hline & $44,4[\mathrm{~W}]$ & $<0.01-0.97$ & $0.025-2.42$ & VISCONTI et al., 1999 \\
\hline Israel & $100[\mathrm{R}]$ & $0.0036-0.0654$ & $0.009-0.16$ & REMIRO et al., 2013 \\
\hline \multirow[t]{4}{*}{ Portugal } & $100[\mathrm{R}]$ & $0.03-0.25$ & $0.075-0.63$ & SHUNDO et al., 2006 \\
\hline & $25.7[\mathrm{R}]$ & $<1.00-1.23$ & $2.50-3.08$ & PENA et al., 2010 \\
\hline & $12[\mathrm{~W}]$ & $<1.00-2.40[33 \%]^{\mathrm{b}}$ & $2.50-6.00$ & PENA et al., 2010 \\
\hline & $6.7[\mathrm{~W} ; \mathrm{R}]$ & $<0.41-0.45$ & $1.02-1.12$ & FERNANDES et al. 2013 \\
\hline Russia & $43[\mathrm{R}]$ & $<1,80-4,40[29 \%]^{\mathrm{b}}$ & $4.50-11.00$ & RUSANOVA et al., 2009 \\
\hline Tunisia & $85[\mathrm{R}]$ & $<0.09-1.50$ & $0.225-3.75$ & LASRAM et al., 2013 \\
\hline \multirow[t]{3}{*}{ Turkey } & $100[\mathrm{~B}]$ & $0.25-1.80$ & $0.65-4.50$ & ALTIOKKA et al., 2009 \\
\hline & $100[\mathrm{R}]$ & $0.0029-0.101$ & $0.005-0.25$ & REMIRO et al., 2013 \\
\hline & $100[\mathrm{R}]$ & $0.39-7.96[70 \%]^{\mathrm{b}}$ & $0.97-19.90^{\mathrm{d}}$ & ALTIOKKA et al., 2009 \\
\hline \multirow[t]{2}{*}{ Uruguay } & $33[\mathrm{R}]$ & $<0.03$ & $<0.075$ & SHUNDO et al., 2006 \\
\hline & $\mathrm{ND}[\mathrm{R}]$ & $<0.2$ & $<0.50$ & HOELTZ et al., 2012 \\
\hline Chile, Spain and Australia & 13 [R;W;RO] & $<0.03-0.26$ & $<0.075-0.65$ & ALVARADO et al., 2013 \\
\hline
\end{tabular}

${ }^{a}$ Analyzed samples: [W] white wine; [R] Red wine, [RO] Vinho rosé and [S] special wine.

${ }^{\mathrm{b}}$ Percentage of samples with OTA concentration above $2 \mathrm{ng} \mathrm{mL} \mathrm{mL}^{-1}$ (considering all samples evaluated by the authors).

${ }^{\mathrm{c}}$ Estimated exposure to OTA (ng Kkg${ }^{-1}$ bw day ${ }^{-1}$ ) for adults (considering the body weight of $60 \mathrm{~kg}$ ) through the daily consumption of $150 \mathrm{~mL}$ of wine.

${ }^{\mathrm{d}}$ Estimated exposure to OTA may be greater than the provisional tolerable intake for this mycotoxin $\left(16 \mathrm{ng} \mathrm{kg}^{-1} \mathrm{bw} \mathrm{day}^{-1}\right)(\mathrm{JECFA}, 2007)$, if these samples were consumed.

${ }^{\mathrm{e}}$ Wines produced in various countries were evaluated including: Germany, Austria, Spain, France, Italy, Hungary and Portugal.

Ciência Rural, v.46, n.1, jan, 2016. 
exposure to the toxin is higher than PTWI there is a risk related to the consume of products containing OTA. The OTA estimated exposure through the consumption of grape juice and wine may be calculated according to the equation:

$E E=\frac{C \times O T A}{P C}$

equation 1

where, EE: estimated exposure (ng kg-1 bw day-1), C: the consumption of juice and wine $\left(\mathrm{mL} \mathrm{day}^{-1}\right)$, OTA: OTA level (ng mL $\left.{ }^{-1}\right)$ and BW: body weight $(60 \mathrm{~kg}$ for adults and $20 \mathrm{~kg}$ for children).

The OTA values found in grape juice (Table 1) and wine (Table 2) were used in calculation of estimated exposure to this toxin. Daily consumption of juice was estimated taking into consideration: (i) a cup $(200 \mathrm{~mL})$ of grape juice consumed by children, since this beverage has been introduced in meals of public schools in the states of Rio Grande do Sul and Santa Catarina (RIO GRANDE DO SUL, 2009; SANTA CATARINA, 2009) and this amount has been daily consumed by children, (ii) $145 \mathrm{~mL}$ of juice consumed by adults as established by the Consumer Expenditure Survey conducted by the Brazilian Institute of Geography and Statistics (IBGE, 2011) and (iii) a glass of wine $(150 \mathrm{~mL})$ per day recommended by some searches due to the presence of polyphenolic compounds.

The studies focused on the incidence of OTA in juices are incipient in relation to research on the occurrence of this toxin in wine. Levels of OTA ranged from $<0.003$ to $6.72 \mathrm{ng} \mathrm{mL}^{-1}$ and 0.00003 to $27.79 \mathrm{ng} \mathrm{mL}^{-1}$, for juice and wine, respectively. According to table 1, only a paper published in the literature (WOESE, 2000) showed juice samples (marketed in Germany) with OTA levels above $2 \mathrm{ng} \mathrm{mL} \mathrm{m}^{-1}$ (the maximum limit adopted by European and Brazilian law). Thus, the consumption of these grape juices represents a risk situation, since the estimated exposure to OTA (16.24 and 67.20ng kg-1 bw day $^{-1}$ for adults and children, respectively) was higher than the PTWI (16ng kg-1 bw day-1) defined as safe by JECFA.

OTA levels in juices were lower than $2 \mathrm{ng} \mathrm{mL} \mathrm{m}^{-1}$ in other studies cited in table 1 , in which the occurrence of this mycotoxin was evaluated, including samples from Brazil (ROSA et al., 2004; SHUNDO et al., 2006), China (CAO et al., 2013), Spain (BELLI et al., 2004), Malaysia (LEE et al., 2012) and Switzerland (ZIMMERLI \& DICK, 1996). In these cases, the OTA exposure through consumption of juice has not represented a health risk, since the estimated exposure to this toxin were lower than the value established as PTWI by JECFA
(ZIMMERLI \& DICK, 1996; ROSA et al., 2004; BELLI et al., 2004; SHUNDO et al., 2006; LEE et al., 2012; CAO et al., 2013).

In wines (Table 2), VISCONTI et al. (1999), VALERO et al. (2008), BRERA et al. (2008) and ALTIOKKA et al. (2009) presented samples in which the OTA exposure was noteworthy. In the evaluation of wines from Turkey, for example, $70 \%$ of the samples had levels greater than $2 \mathrm{ng} \mathrm{mL}^{-1}$ and exposure to OTA could reach $19.90 \mathrm{ng} \mathrm{kg}^{-1}$ bw day $^{-1}$ (ALTIOKKA et al., 2009). In Italian wines, similar estimated exposure $\left(19,01\right.$ and $18,75 \mathrm{ng} \mathrm{kg}^{-1}$ bw day $^{-1}$ ) was observed by VISCONTI et al. (1999) and BRERA et al. (2008), respectively. OTA was found in these wines in concentration exceeding $2 \mathrm{ng} \mathrm{mL} \mathrm{mL}^{-1}$ in $2.8 \%$ (VISCONTI et al., 1999) and $87 \%$ (BRERA et al., 2008) of samples.

Considering data of table 2, the highest estimated exposure to OTA (69.50ng kg-1 bw day-1) was observed in special wines evaluated by VALERO et al. (2008). In these wines, the OTA levels reached $27.79 \mathrm{ng} \mathrm{mL}^{-1}$. The maximum limit established for OTA of $2 \mathrm{ng} \mathrm{mL} \mathrm{m}^{-1}$ is not applied for special wines. In this type of wine, the fermentation step is stopped by the addition of a given amount of grape distilled as mentioned above. This procedure is performed in order to obtain sweeter wines, as part of sugars was not consumed by yeast when the fermentation is stopped. Results obtained by VALERO et al. (2008) may indicate that fermentation is important role in the degradation of this mycotoxin.

Occurrence of OTA in wines at levels above 2 ng $\mathrm{mL}^{-1}$ (Table 2) was observed in several countries including Brazil (WELKE et al., 2010), China (ZHANG et al., 2013), Spain (BELLI et al., 2004), Greece (SARIGIANNIS et al., 2014), Italy (VISCONTI et al., 1999; BRERA et al., 2008; PRELLE et al., 2013), Portugal (PEN et al., 2010), Russia (RUSANOVA et al., 2009) and Turkey (ALTIOKKA et al., 2009). These results demonstrate that the OTA exposure through wine consumption may be a concern at these countries. In addition, samples containing high levels of OTA were detected in Italy (BRERA et al., 2008), Turkey (ALTIOKKA et al., 2009) and China (ZHANG et al., 2013), where the occurrence of OTA was verified in $95 \%, 85 \%$ and $57 \%$ of the samples, respectively. In other studies, despite the OTA has been found in wines from Africa (REMIRO et al., 2013), Spain (CHIODINI et al., 2006) and Israel (REMIRO et al., 2013) at low levels ( 0.0844 to $0.455,0.007$ to 0.009 and 0.003 to 0.0654 , respectively), this toxin was found in $100 \%$ of the samples produced in these countries. In these cases, 
the amount and frequency of wine consumption can be determining factors for exposure to OTA pose a risk to health.

\section{CONCLUSION}

The OTA is present in several countries as a contaminant in grapes, juice and wine. In Europe, several studies have been conducted in order to map the areas where the development of mycotoxigenic fungi is more favorable, and consequently the production of OTA. In Brazil, these studies are still incipient.

A. niger and $A$. carbonarius are mainly responsible for the fungic contamination of grapes. Moreover, these fungal species should be highlighted both for its high incidence and as for its great capacity to produce OTA. Factors that influence the OTA levels in juices and wines are well established in the literature. The grape variety used in winemaking, the presence of physical damage in surface of grapes and climatic conditions are frequently related to occurrence of OTA.

The estimation of OTA exposure through the consumption of juice and wine revealed that few studies showed samples in which the consumption could pose health risk. The estimated exposure to OTA was higher than the tolerable intake for this mycotoxin in rare cases. However, the frequency of occurrence of OTA was high. In addition, in some cases, the number of samples with OTA levels above the maximum limit established was significant in some countries.

Although the evaluations published in literature indicate that the OTA exposure through the consume of grape juice and wine poses risk to health in few cases, only the periodic survey on the levels of this toxin may ensure the security related to the consume of these products. The incidence of OTA in juices and wines must be constantly monitored due to the following factors: (i) toxic effects of OTA, (ii) evaluation of a reduced number of samples produced in Brazil, (iii) recent publication of Brazilian legislation establishing maximum limits for this mycotoxin, (iv) introduction of the grape juice in school meals and recommendation of regular intake of wine because of its functional properties.

\section{ACKNOWLEDGEMENTS}

The authors thank Conselho Nacional de Desenvolvimento Científico e Tecnológico (CNPq), Fundação de Amparo à Pesquisa do Estado do Rio Grande do Sul (FAPERGS) and Coordenação de Aperfeiçoamento de Pessoal de Nível Superior (CAPES) for financial support and scholarships.

\section{REFERENCES}

AGÊNCIA NACIONAL DE VIGILÂNCIA SANITÁRIA (ANVISA). Regulamento Técnico sobre os limites máximos tolerados (LMT) para micotoxinas em alimentos, Resolução RDC n.7, fevereiro de 2011. Diário Oficial da União, Poder Executivo, n.37, 2011.

ALTIOKKA, G. et al. Determination of Ochratoxin A in Turkish wines. Journal of Food and Drug Analysis, v.17, n.6, p.467-473, 2009. Available from: <http://www.fda.gov.tw/en/ publishJFDAListContent.aspx?id=1641\&chk $=$ de $5 \mathrm{~d} 0 \mathrm{cc} 2-\mathrm{c} 810$ 40a7-8cf2-4e2482bb098a\&param=pn\%3D44\%26cid\%3D\%26sub cid\%3D>. Accessed: Mar. 20, 2015.

ALVARADO, M. et al. Fast and selective determination of Ochratoxin A in wines using an optimized and validated liquid chromatographic method. Food Analytical Methods, v.6, p.621629, 2013. Available from: <http://dx.doi.org/10.1007/s12161012-9446-y>. Accessed: Mar. 20, 2015. doi: 10.1007/s12161012-9446-y.

BELLI, N. et al. Ochratoxin A in wines, musts and grape juices from Spain. Journal of the Science of Food and Agriculture, v.84, n.6, p.591-594, 2004. Available from: <http://onlinelibrary. wiley.com/doi/10.1002/jsfa.1702/pdf $>$. Accessed: Nov. 15, 2014. doi: $10.1002 /$ jsfa. 1702 .

BELLI, N. et al. Skim damage, high temperature and relative humidity as detrimental factors for Aspergillus carbonarius infection and ochratoxin A production in grapes. Food Control, v.18, p.1343-1349, 2007. Available from: <http://dx.doi. org/10.1016/j.foodcont.2006.02.014>. Accessed: Dec. 15, 2014. doi: 10.1016/j.foodcont.2006.02.014.

BRERA, C. et al. Ochratoxin A contamination in Italian wine samples and evaluation of the exposure in the Italian population. Journal of Agricultural and Food Chemistry, v.56, p.1061110618, 2008. Available from: <http://www.ncbi.nlm.nih.gov/ pubmed/18939845>. Accessed: Dec. 15, 2014. doi: 10.1021/ jf8016282.

CABAÑES, F.J. et al. What is the source of ochratoxin A in wine? International Journal of Food Microbiology, v.79, p.213-215, 2002. Available from: <http://http://dx.doi.org/10.1016/S01681605(02)00087-9>. Accessed: Dec. 20, 2014. doi: 10.1016/ S0168-1605(02)00087-9.

CAO, J.L. et al. Moleculaly imprinted polymer-based solid phase clean-up for analysis of ochratoxin A in beer, red wine, and grape juice. Journal of Separation Science, v.36, p.12911297, 2013. Available from: <http://www.ncbi.nlm.nih.gov/ pubmed/23471605>. Accessed: Dec. 20, 2014. doi: 10.1002/ jssc. 201201055

CHIODINI, A.M. et al. Ochratoxin A contents in wine: comparison of organically and conventionally produced products. Journal of Agricultural and Food Chemistry, v.54, p.7399-7404, 2006. Available from: $<$ http://dx.doi.org/10.1021/jf0613482 >. Accessed: Mar. 20, 2015. doi: 10.1021/jf0613482.

CHIOTTA, M.L. et al. Aspergillus section Nigri species isolated from different wine-grape growing regions in Argentina. International Journal of Food Microbiology, v.136, p.137-141, 2009. Available from: <http://dx.doi.org/10.1016/j.ijfoodmicro.2009.08.013>. Accessed: Dec. 20, 2014. doi: 10.1016/j.ijfoodmicro.2009.08.013. 
CLOUVEL, P. et al. Wine contamination by ochratoxin A in relation to vine environment. International Journal of Food Microbiology, v.123, p.74-80, 2008. Available from: $\quad<$ http://www.sciencedirect.com/science/article/pii/ S0168160507006873>. Accessed: Dec. 20, 2014. doi: 10.1016/j. ijfoodmicro.2007.12.003.

EUROPEAN COMMISSION (2006). Commission Regulation (EC) n. 1881/ (2006) of 19 December 2006 setting maximum levels for certain contaminants in foodstuffs. Official Journal of European Union, L365, 6 -24.

FERNANDES P.J. et al. A survey of the occurrence of ochratoxin A in Madeira wines based on a modified QuEChERS extraction procedure combined with liquid chromatography-triple quadrupole tandem mass spectrometry. Food Research International, v.54, p.293-301, 2013. Available from: <http://dx.doi.org/10.1016/j. foodres.2013.07.020>. Accessed: Mar. 15, 2015. doi: 10.1016/j. foodres.2013.07.020.

GIOVANNOLI, C. et al. Determination of Ochratoxin A in Italian Red Wines by molecularly imprinted solid phase extraction and HPLC analysis. Journal of Agricultural and Food Chemistry, v.62, p.5220-5225, 2014. Available from: <http:/ dx.doi.org/10.1021/jf5010995>. Accessed: Mar. 20, 2015. doi: $10.1021 /$ jf5010995.

HOELTZ, M. et al. Ocratoxina A: análise da qualidade de vinhos brasileiros e importados. Brazilian Journal of Food Technology, v.15, p.58-63, 2012. Available from: <http://dx.doi.org/10.1590/ S1981-67232012005000039>. Accessed: Dec. 14, 2014. doi: 10.1590/S1981-67232012005000039.

IARC. Ochratoxin A. In: IARC Monographs on the Evaluation of Carcinogenic Risks to Humans, Some Naturally Occurring Substances. International Agency for Research on Cancer, v.56, p.489-521, 1993.

IBGE (INSTITUTO BRASILEIRO DE GEOGRAFIA $\mathrm{E}$ ESTATÍSTICA). 2011. POF - Pesquisa de Orçamentos Familiares. Online. Available from: <http://www.ibge.gov.br/ home/estatistica>. Accessed: Nov. 15, 2014.

JECFA (2007). Joint FAO/WHO Expert Committee on Food Additives. Safety evaluations on certain mycotoxins in food. Available from: <http://www.inchem.org/documents/jecfa/ jecmono/v47je01.htm>. Accessed: Nov. 15, 2014.

LASRAM, S. et al. Ochratoxin A and ochratoxigenic black Aspergillus species in Tunisian grapes cultivated in different geographic areas. Food Control, v.25, p.75-80, 2012. Available from: <http://dx.doi.org/10.1016/j.foodcont.2011.10.006> Accessed: Mar. 20, 2015. doi: 10.1016/j.foodcont.2011.10.006.

LASRAM, S. et al. Occurrence of ochratoxin A in domestic beers and wines from Tunisia by immunoaffinity clean-up and liquid chromatography. Food Additives \& Contaminants: Part B: Surveillance, v.6, p.1-5, 2013. Available from: $<$ http://dx.doi.org/ 10.1080/19393210.2012.716453>. Accessed: Mar. 20, 2015. doi $10.1080 / 19393210.2012 .716453$.

LEE, T.P. Molecularly imprinted polymer as sorbent in microsolid phase extraction of ochratoxin A in coffee, grape juice and urine. Talanta, v.88, p.129-135, 2012. Available from: <http:// www.sciencedirect.com/science/article/pii/S0039914011009210>. Accessed: Mar. 20, 2015. doi: 10.1016/j.talanta.2011.10.021.
LUCCHETTA, G. et al. Occurrence of Black Aspergilli and Ochratoxin A on Grapes in Italy. Toxins, v.2, p.840-855, 2010. Available from: <http://www.mdpi.com/2072-6651/2/4/840>. Accessed: Dec. 15, 2014. doi: 10.3390/toxins 2040840 .

MAO, J. Quantification of ochratoxin A in red wines by conventional HPLC-FLD using a column packed with coreeshell particles. Food Control, v.32, p.505-511, 2013. Available from: $<$ http://dx.doi.org/10.1016/j.foodcont.2013.01.016>. Accessed: Mar. 15, 2015. doi: 10.1016/j.foodcont.2013.01.016.

MARROQUÍN-CARDONA, A.G.. et al. Mycotoxins in a changing global environment - A review. Food and Chemical Toxicology, v.69, p.220-230, 2014. Available from: <http://www.sciencedirect. com/science/article/pii/S0278691514002075>. Accessed: Dec. 15, 2014. doi:10.1016/j.fct.2014.04.025.

NG, W. et al. Ochratoxin A in wine and grape juice sold in Canadá. Food Additives and Contaminants, v.21, n.10, p.971-981, 2004. Available from: $<$ http://www.ncbi.nlm.nih.gov/pubmed/15712522>. Accessed: Dec. 15, 2014. doi: 10.1080/02652030400000653.

OTTENEDER, H.; MAJERUS, P. Occurrence of Ochratoxin $\mathrm{A}$ in wines and its geographical origin. Food Additives and contaminants, v.17, n.9, p.793-798, 2000. Available from: $<$ http://dx.doi.org/10.1080/026520300415345>. Accessed: Nov. 20, 2014. doi: 10.1080/026520300415345.

PENA, A. et al. Ochratoxin A survey in Portuguese wine by LC-FD with direct injection. Talanta, v.82, p.1556-1561, 2010. Available from: $<$ http://www.sciencedirect.com/science/article/pii/ S0039914010005710>. Accessed: Dec. 15, 2014. doi: 10.1016/j. talanta.2010.07.041.

PIETRI, A. et al. Occurrence of Ochratoxin A in Italian wines. Food Additives and contaminants, v.17, n.7, p.647654, 2001. Available from: <http://www.tandfonline.com/doi/ abs/10.1080/02652030119480>. Accessed: Dec. 15, 2014. doi: $10.1080 / 02652030119480$.

PONSONE, M.L. et al. Ochratoxin A and ochratoxigenic Aspergillus species in Argentinean wine grapes cultivated under organic and non-organic systems. International Journal of Food Microbiology, v.114, p.131-135, 2007. Available from: <http:// www.sciencedirect.com/science/article/pii/S0168160506003916>. Accessed: Dec. 20, 2014. doi: 10.1016/j.ijfoodmicro.2006.07.001.

PRELLE, A. et al. Comparison of clean-up methods for Ochratoxin A on wine, beer, roasted coffee and chili commercialized in Italy. Toxins, v.5, p.1827-1844, 2013. Available from: $<$ http://dx.doi. org/10.3390/toxins5101827>. Accessed: Mar. 20, 2015. doi: $10.3390 /$ toxins 5101827 .

QUINTELA, S. et al. Ochratoxin A in Spanish exportation wine market. Food Control, v.25, p.501-504, 2012. Available from: $<$ http://dx.doi.org/10.1016/j.foodcont.2011.11.02>. Accessed: Dec. 15, 2014. doi:10.1016/j.foodcont.2011.11.02.

RATOLA, N. el al. Evolution of ochratoxin A content from must to wine in Port Wine microvinification. Analytical and Bioanalytical Chemistry, v.382, p.405-411, 2005. Available from: $<$ http://link. springer.com/article/10.1007\%2Fs00216-005-3176-6>. Accessed: Dec. 15, 2014. doi: 10.1007/s00216-005-3176-6.

RIO GRANDE DO SUL. Lei n. 13.247, de 08 de setembro de 2009. Inclui o suco de uva e o suco de laranja produzidos no Estado 
do Rio Grande do Sul no cardápio da merenda escolar da rede pública estadual de ensino.

REMIRO, R. et al. Levels of ochratoxins in Mediterranean red wines. Food Control, v.32, p.63-68, 2013. Available from: $<$ http://dx.doi.org/10.1016/j.foodcont.2012.11.040.>. Accessed: Nov. 15, 2014. doi: 10.1016/j.foodcont.2012.11.040.

REMIRO, R. et al. Quantification of ochratoxin A and five analogs in Navarra red wines. Food Control, v.27, p.139145, 2012. Available from: <http://dx.doi.org/10.1016/j. foodcont.2012.03.006>. Accessed: Nov. 15, 2014. doi: 10.1016/j. foodcont.2012.03.006.

ROCHA, E.B. et al. Mycotoxins and their effects on human and animal health. Food Control. v. 36, p. 159-165, 2014. Disponível: $<$ http://dx.doi.org/10.1016/j.foodcont.2013.08.021>. Accessed: Dez. 14, 2014. doi: 10.1016/j.foodcont.2013.08.021.

ROSA, C.A.R. et al. Occurrence of ochratoxin A in wine and grape juice marketed in Rio de Janeiro, Brazil. Food Additives and Contaminants, v.21, p.358-364, 2004. Available from: <http:// dx.doi.org/10.1080/02652030310001639549>. Accessed: Nov. 15, 2014. doi: 10.1080/02652030310001639549.

RUSANOVA, T.Y. et al. Non-instrumental immunochemical tests for rapid ochratoxin A detection in red wine. Analytica Chimica Acta, v.653, p.97-102, 2009. Available from: <http://dx.doi. org/10.1016/j.aca.2009.08.036>. Accessed: Dec. 15, 2014. doi: 10.1016/j.aca.2009.08.036

SANTA CATARINA. Lei n. 14.995, de 16 de dezembro de 2009. Inclui na merenda escolar dos alunos da rede estadual de ensino, suco de uva produzido em Santa Catarina. Available from: $<$ http://server03 pge.sc.gov.br/LegislacaoEstadual/2009/014995-011-0-2009-001. htm>. Accessed: Dec. 14, 2014.

SARIGIANNIS, Y. et al. Ochratoxin A levels in Greek retail wines. Food Control, v.42, p.139-143, 2014. Available from: <http:// www.sciencedirect.com/science/article/pii/S0956713514000620>. Accessed: Dec. 14, 2014. doi: 10.1002/jsfa.1300.

SHUNDO, L. et al. Ochratoxin A in wines and grape juices commercialized in the city of São Paulo, Brazil. Brazilian Journal of Microbiology, v.37, p.533-537, 2006. Available from: <http://dx.doi.org/10.1590/S1517-83822006000400024>. Accessed: Nov. 15, 2014.

TEIXEIRA, T. et al. Determination of ochratoxin A in wine from the southern region of Brazil by thin layer chromatography with a charge-coupled detector. Food Additives and Contaminants, v.4, p.289-293, 2011. Available from: $<\mathrm{http}: / /$ dx.doi.org/10.1080/1939 3210.2011.638088>. Accessed: Dec. 15, 2014.

TERRA, M.F. et al. Detection of ochratoxin A in tropical wine and grape juice from Brazil. Journal Science Food Agriculture, v.93, p.890-894, 2012. Available from: <http://www.ncbi.nlm. nih.gov/pubmed/22836915>. Accessed: Mar. 15, 2015. doi: $10.1002 /$ jsfa. 5817 .
VALERO, A. et al. Survey: ochratoxin A in European special wines. Food Chemistry, v.108, p.593-599, 2008. Available from: $<$ http://dx.doi.org/10.1016/j.foodchem.2007.11.040>. Accessed: Dec. 15, 2014. doi: 10.1016/j.foodchem.2007.11.040.

VISCONTI, A. et al. Determination of ochratoxin A in wine by means of immunoaffinity column clean-up and high-performance liquid chromatography. Journal of Chromatography, v.864, p.89-101, 1999. Available from: <http://dx.doi.org/10.1016/ S0021-9673(99)00996-6>. Accessed: Dec. 04, 2014. doi: 10.1016/S0021-9673(99)00996-6.

WELKE, J.E. et al. Aspectos relacionados à presença de fungos toxigênicos em uvas e ocratoxina A em vinhos. Ciência Rural, v.39, n.8, p.2567-2575, 2009. Available from: <http://dx.doi. org/10.1590/S0103-84782009005000201>. Accessed: Dec. 15, 2014. doi: $10.1590 / \mathrm{S} 0103-84782009005000201$.

WELKE, J.E. et al. Determination of Ochratoxin A in wine by high-performance thin-layer chromatography using charged coupled device. Journal Brazilian Chemical Society, v.21, p.441-446, 2010. Available from: <http://dx.doi.org/10.1590/ S0103-50532010000300007>. Accessed: Dec. 15, 2014 . doi: 10.1590/S0103-50532010000300007.

WOESE, K. Ochratoxin A in grape juice and wine. Mycotoxin Research, v.16, p.132-135, 2000. Available from: <http://dx.doi. org/10.1007/BF02943001>. Accessed: Dec. 15, 2014 . doi: 10.1007/BF02943001.

WU, J. et al. Occurrence of Ochratoxin $\mathrm{A}$ in wine and beer samples from China. Food Additives and Contaminants, v.4, p.52-56, 2011. Available from: <http://dx.doi.org/10.10 80/19393210.2010.535909>. Accessed: Dec. 02, 2014. doi: $10.1080 / 19393210.2010 .535909$.

XIANG, L. et al. Health benefits of wine: don't expect resveratrol too much. Food Chemistry, v.156, p.258263, 2014. Available from: <http://dx.doi.org/10.1016/j. foodchem.2014.01.006>. Accessed: Dec. 03, 2014. doi: $10.1016 /$ j.foodchem. 2014.01 .006 .

ZHANG, X. et al. Occurrence of Ochratoxin A in Chinese wines: influence of local meteorological parameters. European Food Research and Technology, v.236, p.277-283, 2013. Available from: <http://dx.doi.org/10.1007s00217-012-1886-5>. Accessed: Dec. 03, 2014. doi: 10.1007s00217-012-1886-5.

ZHONG, Q.D et al. Exposure Assessment to Ochratoxin A in Chinese Wine. Journal of Agricultural and Food Chemistry, v.62, p.8908-8913, 2014. Available from: $<$ http://pubs.acs.org/doi/ abs/10.1021/jf500713x>. Accessed: Dec. 14, 2014. doi: 10.1021/ jf500713x.

ZIMMERLI, B.; DICK, R. Ochratoxin A in table wine and grape juice. Occurrence and risk assessment. Food Additives and contaminants, v.13, n.6, p.655-668, 1996. Available from: $<$ http://dx.doi.org/10.1080/02652039609374451>. Accessed: Dec. 15,2014 . doi: 10.1080/02652039609374451. 